\title{
MOST ABUNDANCE DIATOM TAXA OF RIVERS IN TURKEY AND IRAN
}

\section{TAHIR ATICI ${ }^{1} \&$ MASOUMEH SHAMS ${ }^{2}$}

${ }^{I}$ Gazi, University Gazi Educationfaculty, Biology Department, Besevler-Ankara

${ }^{2}$ Department of Biology, Faculty Of Science, University of Isfahan, Islamicrepublic of Iran

\begin{abstract}
The study of diatoms is necessary because they are the sources of oxygen in rivers, and also constitute the basic primary productivity chain and are used in determining water pollution levels. However, in this study some large rivers of Turkey and Iran were compared in this respect and it was thought that the spread of diatom species would contribute to Turkey and Iran diatom species. In the rivers, a lot of diatoms which are known as pollution indicator only Achnantheslanceolata(BrébissonexKützing)Grunow,Caloneisventricosa(Ehrenberg)F.Meister,Cyclotellameneghiniana Kützing, Diatomaelongatum(Lyngbye) C. Agardh, Gomphonemaolivaceum(Hornemann) Brébisson, Nitzschiasigmoidea(Nitzsch) W. Smith, Pinnulariabrebissonii(Kützing) Rabenhorst, Rhoicospheniacurvata(Kützing) Grunow, Nitzschia palea(Kütz.)W. Sm., Ulnariaacus (Kütz.) M. Aboal, Ulnaria ulna (Nitzsch) Compêre and and Gomphonematruncatum Ehrenberg in the Turkey and Iran rivers. The aim of this study is, to assess the diatom of Iranian rivers and evaluate as abundance relation to Turkey rivers.
\end{abstract}

KEYWORDS: Abundant, Diatoms, Rivers, Turkey \& Iran

Received: Sep 12, 2017; Accepted: Oct 02, 2017; Published: Nov 08, 2017; Paper Id.: IJBRDEC20176

\section{INTRODUCTION}

Turkey is drained by 107 major rivers, each with a catchment larger than $1500 \mathrm{~km}^{2}$. Kuzılırmak is the longest river (1355 km), followed by the Euphrates (Firat; $1263 \mathrm{~km}$ in Turkey), Tigris (Dicle; $523 \mathrm{~km}$ in Turkey), Seyhan (560 km), Aras (548 km in Turkey), Yeşilırmak (519 km), Ceyhan (509 km), Coruh (442 km in Turkey), Gediz (400 km), Susurluk (321 km), Greater Meander (307 km) and Smaller Meander (174 km). Of these, the Euphrates, Tigris, Meriç, Çoruh, Aras, and Asi are Transboundary Rivers.

Most Iranianriversareseasonal in flow, relativelyshort in length, andshallow in depth. Of Iran'smajorrivers, five flow into the PersianGulf, these being theDez (401 km), Karkheh (902 km), Karoon(945 km,Diyala (445 km), and Lower Zab Rivers (400 km). Four, the Aras (450 km in Iran), SefidRud (666 km), andAtrekRivers (666 km), Jajrood River $(140 \mathrm{~km})$ flow into the Caspian Sea. Two others flow into smaller inland basins, namely the Zayandeh (400 km) and Aji Chay (265 km).

The study of diatoms is necessary because, they are the sources of oxygen in rivers, and also constitute the basic primary productivity chain and are used in determining water pollution levels. However, this study will contribute to the diatom flora of Turkey. The benefit of freshwater as an environmental resource, which can be used to the potential benefit for humanity and environment, cannot be over emphasized because, the diversity of fresh water diatoms is enormous. Although, algae constitute a fundamental part of the aquatic food chains, only few research papers deal with the freshwater or marine diatoms of Iranian environment. Some authors have studied the seasonal distribution of phytoplankton (Moghadam, 1976) in Iran. InTurkey most diatom species detected in 
Nilüfer Stream(Dere, et. al., 2002), Sakarya River (Atıcı \&Yıldız, 1996), İncesu Creek (Gönülol\&Aslan 1992)river Yeşilırmak (Pabuçcu\&Altuner 1999, Soylu \&Gönülol 2003), Kızılırmak (Dere \& Sivacı, 1995, Yıldız \&Özkıran, 1991)river Asi (Şen et. al., 1997)and Çoruh River (Atıcı \& Obalı, 1999-2000). Diatomswereused as an indicator of pollution in a small section of the Zayandeh River in Isfahan, Iran by Moghadam (1976) Haraz River (Khosravi-Rineh, 2010) andAfsharzadeh et al., 2003. In recent years, Soltanpour-Gargari et al., (2011) reported 155 diatom tax from Ramsar in the north west Iran.

Jamalo et al.,(2006) stated that, 51 species were reported on Epilithon Diatoms of Jajrood River, respectively. Also, some studies, on the diatoms communities in Mesopotamia were conducted by Hirano, (1973) in Hormozgan Province and in the river Hevigh, Gulian Province. The diatoms of the coastal area of the Caspian Sea(Nasrollahet all., 2012), with hundreds of large and small tributaries have received little attentional; though diatoms, especially the fresh water species, are the major group of algae. The aim of this study is, to assess the diatom flora of Iranian fresh water ecosystems and evaluate the relation to Turkey Rivers. Moghadam (1976) and Afsharzadeh et al., (2003), observed a total of 38 and 113 species, respectively from the Zayandeh Rood River in central Iran. The following taxa were also found in the Tajen River (Masoudianet. Al., 2009): Amphoraovalis, Cocconeispediculus, Cyclotellameneghiniana, Cymbellahelvetica, Diatomavulgarismorphotypevulgaris, Nitzschiapalea, Nitzschiasigmoidea.

Generally, on the sediments of the rivers, there is Diatomahiemale var. mesoden, Ceratoneis arcus, Fragilariacapucina, Ulnariaulna, Gyrosigmaacuminatum, Naviculalanceolata, Gomphonemaparvulum, Hantzschiaamphioxys, Nitzschialinearis and N.hungarica species were discovered in large numbers and were widespread. Among these, Ulnariaulna and Nitzschiahungarica species, on the sediments of the stream Ankara and some others on the sediments of the river Sakarya, river Çoruh and the stream Porsuk, were widespread and also were detected in large numbers. On the sediments of Aras (part of Turkey and Part of Iran), apart from Nitzschialinearis, all the other species were detected. In addition, these species of Diatomaelangatum, Meridioncirculare, Ulnariacapitata, Navicularadiosa, Pinnulariamesolepta, Cymbellaaffinis, C.lanceolata, Gomphonemasubclavatu and Nitzschiadubia existed on various kinds of plants and rocks, in the river Çoruh and the others are seen in the large numbers, on the various kinds of plants and rocks in the river Sakarya. In the river Aras, except for the species of Cymbellalanceolata, Denticulaelegans, Nitzschiadubia and Gomphonemasubclavatum the others are seen on the various kinds of plants and rocks. In addition, in the river Ankara, similar circumstances were present.

All of the arms of the river, which feed that river, are convenient habitats for trout niche. Therefore, in the river water of studied region, any industrial pollution and home pollution were not observed. In the rivers, a lot of diatoms, which are known as pollution indicators, only Achnantheslanceolata, Caloneisventricosa, Cyclotellameneghiniana, Diatomaelongatum, Gomphonemaolivaceum, Nitzschiasigmoidea, Pinnulariabrebissoni, Rhoicospheniacurvata and Ulnariaulna were found, in less numbers in the Turkeys Rivers.

Numerous phycological investigations have been performed in the different Turkish river and lake basins, and Ehrenberg already published the first study on diatoms in 1845. Subsequent work has concentrated mainly on diatoms, in the phytoplankton, while riverine systems have received less attention. The aim of this study is, to reveal the characteristics of diatom communities, between Iran andTurkish rivers. 


\section{MATERIALS AND METHODS}

A list of taxa reported in these publications was compiled in a table, denoting whether the dominant taxa occurred in rivers. Tables and figures were produced using Microsoft@ Word and Excel 2013.

\section{RESULTS AND CONCLUSIONS}

Of the identified taxa in this study, Achnanthes, Amphora, Caloneis, Cocconeis, Cyclotella, Cymatopleura, Cymbella, Diatoma, Diploneis, Fragilaria, Gomphonema, Navicula, Nitzschia, Pinnularia, Rhizosolenia and Surirella were recorded at the most sampling sites in Iran. Seven diatom species as Amphora commutata, Cymbella affinis, Haslea spicula, Navicula paramutica, Navicula pygmaea, Nitzschia scalpelliformis and Stauroneis anceps var. Anceps were reported byWasylik (1975), from different areas of Iran.

The diatom of the river Çoruh(Atıcı\&Obalı, 1999-2000) of the river Sakarya (Atıcı\&Yıldız, 1996), of the river Aras (Altuner, 1988) of the river Kızılırmak (Yıldız\&Özkıran, 1994), of the river Karasu (Altuner\&Gürbüz, 1988-19891990-1991), of the stream Samsun İncesu (Gönülol\&Aslan 1992) and of the stream Ankara (Y1ldı\&Atıc1, 1996), is similar to diatom distrubition of Zayandeh Rood river (Afsharzadeh et all., 2003) and of the Bahmanshir River (Faal, 2005), in Iran.

Diatoms, which live together with Epipelic, Epiphytic, and Epilithic habitats, are blend plankton in the rivers. Similar findings were able to be observed in the previous researches (Fatemi et. al., 2005), (Gönülol et. al., 1992), Masoleh-Roodkhan River (Sharifinia et. al., 2012), between two country.

Although, the centric diatoms such as Cyclotellameneghiniana and C. ocellata were found in large number in the rivers Sakarya, Kızılırmak, and the stream Ankara, these types were found in a few numbers in the river Çoruh, as they were found in the stream Porsuk (Yıldız, 1987) and Karasu (Gürbüz\&Ertuğrul, 2003). The C. kützünginiana and Melosiragranulata found in few numbers in the river Sakarya and the stream Ankara, were also found in few numbers in the river Çoruh. Among Pennatdiatomes, there are Diatomeelongatum, D. vulgare, Fragilaria intermedia, Ulnariaacus, Didymosphaeniageminata, Naviculagastrum, N. pupula, P. divergens, Nitzchiasigmoide and Surirella ovatavar. Pinnata species were found in large numbers, in the river Sakarya and the stream Ankara, stream Akcay (Solak et al., 2007) Stream and they were found in large numbers, in the phytoplanktons of the river Çoruh as well.

Moghadam (1976) and Afsharzadeh et al., (2003) observed a total of 113 species, respectively from the Zayandeh Rood River in central Iran. Karoon and Dez Rivers (in southernparts) Jaferzadeh et. al., (2004), reported 43 taxa from 21 localities in the central and southeastern parts of Iran. The following taxa were also found in the present study: Amphoraovalis,Cocconeispediculus, Cyclotellameneghiniana, Cymbellahelvetica, Diatomavulgaris, Nitzschiapalea, Nitzschiasigmoidea, which are similar to Masoudian et al., (2009) results. Furthermore, Moghadam (1976) from Zyandeh River and Gargar Rivers Rasti et al.,(2008) were reported 16 taxa, as Amphoraovalis, Cyclotellameneghiniana, Cymatopleuraellipticavar, elliptica, Diatomavulgaris, Fragilariaulnavar. acus, Fragilaria ulna var. ulna, Gomphonema parvulum, Gyrosigma scalproides, Navicula bacillum, Navicula cryptocephala, Navicula viridula var. viridula, Nitzschia palea, Nitzschia sigmoidea, Nitzschia ermicularis, Rhoicosphenia abbreviate, Stauroneis anceps var. anceps. In the following list of diatom taxa number compera Iran and Turkey, the systematic classification has been followed, as far as possible (Figure 1). 


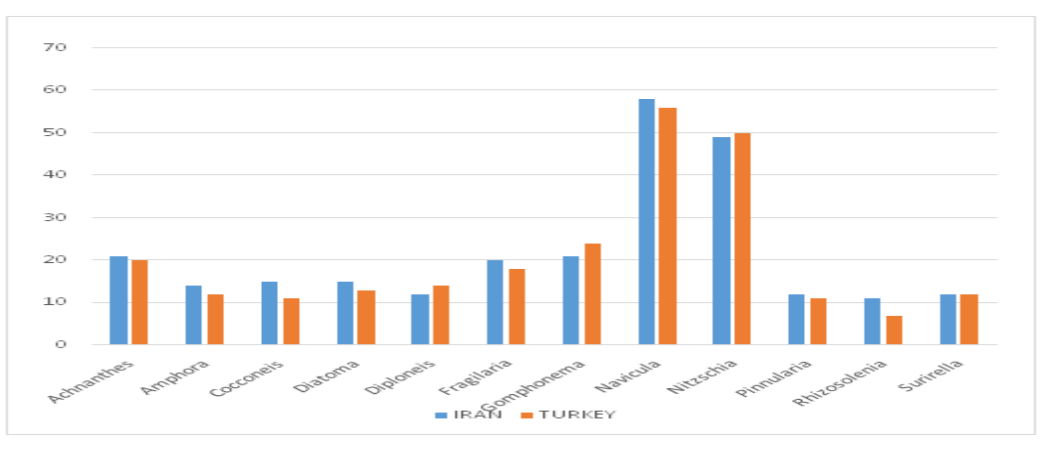

Figure 1: Some Dominant Diatoms Tax a Number Comparison between Iran and Turkey

In regard to this study, centric diatoms have the indicators of euotrophic and pennate diatoms indicator of fresh water,The identified taxa in Iranian river, Amphora ovalis, Caloneisbacillum, Cocconeisplacentula, Cyclotellameneghiniana, Cymatopleurasolea, Cymbellahelvetica, Gomphonematruncatum, Naviculacryptocephala, Naviculasalinarumand Nitzschiapaleawere recorded at the most sampling sites. Seven diatom species Amphora commutata, Cymbellaaffinis, Hasleaspicula, Naviculaparamutica, Naviculapygmaea, NitzschiascalpelliformisandStauroneis anceps var. anceps were reported by Wasylik (1975) from different areas of Iran. The following taxa were also found in the present study: Amphora ovalis, Cocconeispediculus, Cyclotellameneghiniana, Cymbellahelvetica, Diatoma vulgaris morphotype vulgaris, Nitzschiapalea, Nitzschiasigmoidea. Study some of Turkish rivers conducted epilithic algae; Nitzschia dissipate, Naviculaexigua, Naviculacuspidata, Cymbellacistula Gomphonemaminutum, Gomphonemaolivaceum and Surirella the most dominant species, identified as species. In anepipelic algae; Navicula, Nitzcschia, Cymbella, to Surirella, and Pinnularia, belonging to taxa have been reported to be intense. In a study conducted in the epilithic algae; Nitcschia, Navicula, Cymbellaand Gomphonema were found to be the dominant genera. All Iranian and Turkish rivers are important confused habitat corridors.

Benthic diatom communities react very quickly to disturbances of the water (e.g. tochanges in the physico chemical conditions of the water or to the pollution, affecting the catchment area), very often by changes of their species composition or diversity, which can vary from species rich tomonotonous communities. Because, of this characteristic, benthic diatom communities are a useful tool, in detecting anthropogenic impacts. Research on diatom communities along river gradients, either at a local, regional or continental scale, has shown the prevalence of (1) down stream gradients (fromfast-flowingo ligotrophic high land rivers to eutrophicrivers of low-elevationplains), (2) chemical factors related to catchmentgeology, mostly alkalinity and $\mathrm{pH}$, and (3) latitudinal and altitudinal variation of temperature.

Generally, Turkish river and Iran river basin, by anthropogenic effects unseen regions here because, Cyclotellameneghiniana, Cymbellahalvetica, Synedra ulna and Spirulina subsalsa, taxa have been determined both of them.

\section{REFERENCES}

1. Afsharzadeh, S., T. Nejadsattari, M. Rahiminejad, \&Ebrahimnejad 2003: Study of algal flora in Zayandeh Rood river. Iranian Journal of Biology vol. 14 (1): 32-45.

2. Altuner Z, Gürbüz H, 1988. Karasu Nehrinin epilitik diyatomeleri. IX. Ulusal Biyoloji Kongresi, Sivas, 3(1), 223-230.

3. Altuner Z, Gürbüz H, 1989. Karasu (Fırat) Nehri fitoplanktonu üzerinde bir arasttrma. İstanbul Üniversitesi Su Ürünleri Dergisi 3 (1-2), 151-176. 
4. Altuner Z, Gürbüz H, 1990. Karasu (Fırat) Nehri'nin epilitik ve epifitik algleri üzerinde bir arastırma. X. Ulusal Biyoloji Kongresi, Erzurum 2(1): 193-203.

5. Altuner Z, Gürbüz H, 1991. Karasu (Ftrat) Nehri epipelik alg florası üzerine bir arastırma. Doga TU Botanik 15(3): 253-267.

6. Altuner Z, 1988. A study of the diatom flora of the Aras River, Turkey. Nova Hedwigia 46: 255-263.

7. Atıcı T, Obalı O, 1999. A study on diatoms in upper part of Çoruh River, Turkey. Gazi University Journal of Science 12(3): 473-496.

8. Atıcı T, Obalı O, 2000. Çoruh River's (Bayburt-Turkey) algae (excluding Bacillariophyta). The Herb Journal of Systematic Botany 7(1): 231-247.

9. Atıcı T, Yıldız K, 1996. Sakarya Nehri diatomeleri. Turkish Journal of Botany 20: 119-134.

10. Dere (Ünal) S, Sıvacı R, 1995. Klzılırmak (Sivas, Giris-Çıkıs) epipelik, epifitik, epilitik alg florası. XII. Ulusal Biyoloji Kongresi, Hidrobiyoloji Seksiyonu, Edirne, IV: 180-188.

11. Dere S, Karacaoglu D, Dalkıran N, 2002. A study on theepiphyticalgae of the Nilüfer Stream (Bursa). TurkishJournal of Botany 26: 219-234.

12. Faal, Z. 2012. Seasonal distribution of phytoplankton within tidal period in BahmanshirRiver.Iranian Scientific Fisheries Journal. 21(2): 159-164

13. Fatemi, A. R., Vosughi, G. H., Nikouyan, A. R. and Fallahi, M. 2005. Diatoms diversity and abundance in Iranian waters of the Persian Gulf, Bushehr area. Iranian Scientific Fisheries Journal. 13(4): 111-124.

14. Gönülol A, Öztürk M, Öztürk M, 1996. A check-list of the freshwater algae of Turkey. Ondokuz Mayls Üniversitesi, FenEdebiyat Fakültesi, Fen Dergisi 7(1): 8-46.

15. Gönülol A, Arslan N, 1992. Floristic studies on the algal flora of Samsun-Incesu Stream, Turkey. Turkish Journal of Botany 16: $311-334$.

16. Gürbüz H, Ertugrul M, 2003. Determination of medium elements in algae of Karasu (Firat) River by EDXRF using An Am-241 Excitation Source. Instrumentation Science and Technology 31 (2): 189-196.

17. Gürbüz H, Klvrak E, 2002. Use of epilithic diatoms to evaluate water quality in the Karasu River of Turkey. Journal EnvironmentalBiology 23(3): 239-246.

18. Hirano M. 1973. Freshwater algae from Mesopotamia. Contributions of Biological Laboratory of Kyoto University. 24: 105119.

19. Jamalo, F, Nejadsattari, T. and Fallahian, F. 2006.Epilithon Diatoms of JajroodRiver.Pajouhesh\&Sazandegi Journal. $73:$ 211.

20. Khosravi-Rineh, M., Nejadsattari, T., Fallahian, F., Khavarinejad, R. and Mataji, A. 2010.Identification of different genus of Diatoms in Haraz Rivers and relationship them to physic-chemical factors. Environmental Science and Technology. 12(4): 151-162.

21. Masoudian, N., Fallahian, F., Nejadsattari, T., Mataji, A. and Khavarinejad, R. 2009. Epipelic diatoms and role them in determine of water quality of Tajen River (Mazandaran province). Journal of Iranian bioscience.57-66.

22. Moghadam, F. 1976. Diatoms as indicator of pollution Zayandeh River, Iran. Proceedings of the Academy of Natural Sciences of Philadelphia 127, 281-297. 
23. NasrollahZadeh-Saravi, H., Makhlogh, A., Pourgholam, R. and Rahmati, R. 2012. Strategy of phytoplankton dominant species based on them size in Iranian coasts Caspian Sea southern. Oceanology. 3(10):45-57

24. Jaferzadeh $N$, Rosttami S, Sepehrfar $K$ andLahijanzadeh A. 2004. Identification of theWaterPollutantIndustries in KhuzestanProvinceIranian J EnvHealthSciEng, Vol.1, No.2, pp.36-42.

25. Pabuçcu K, Altuner Z, 1999. Planktonic algal flora of Yesilirmak River (Tokat). Bulletinof Pure\&AppliedScience 17:101-112.

26. Rasti, M., Nabavi, S. M. B., Jafarzadeh, N. and Mobad, P. 2008. Algal flor of periphyton communication based on bed kind in Gargar Rivers. Environmental Journal. 34(46): 73-80.

27. Solak CN, Feher G, Barlas M, Pabuccu K, 2007. Use of epilithic diatoms to evaluate water quality of Akcay Stream (Büyük Menderes River) in Mugla/Turkey. Archiv für Hydrobiologie, Suppl. 161 (3-4) / Large Rivers 17 (3-4): 327-338.

28. Soylu EN, Gönülol A, 2003. Phytoplankton and seasonal variations of the River Yesilırmak, Amasya, Turkey. Turkish Journal of Fisheries and Aquatic Sciences 3: 17-24.

29. Sen B, Alp MT, Özrenk F, 1997. Asi Nehri (Hatay)'nin Akdeniz'e döküldügü kesimdeki diyatomlar (Bacillariophyta) üzerine bir arastırma, XIII. Ulusal Biyoloji Kongresi, İstanbul, 5: 256-265.

30. Sharifinia, M., Imanpour J., Ramezan pour, Z. 2012. Application of category technique in study of diatoms population and them relationship with environmental factors (Masoleh-Roodkhan River). Journal of Microorganisms Biology. 1: 11-22.

31. Soltanpour-Gargari, A., Lodenius, M. and Hinz, F. 2011.Epilithic diatoms Bacillariophycae) from streams in Ramsar, Iran.Acta Bot. Croat. 70 (2), 167-190.

32. Ylldiz K, 1987. Diatoms of the Porsuk River, Turkey. Doga TU Biology 11(3): 162-182.

33. Yıldız K, Atıcı T, 1996. Ankara Çayı diyatomeleri, Gazi Üniversitesi, Fen Edebiyat Fakültesi Dergisi 6: 59-87.

34. Yıldız K, Özkıran Ö, 1991. Diatoms of Kızılırmak River. Turkish Journal of Botany 15: 166-188.

35. Wasylik, K., 1975: Notes on the freshwater algae of Iran. FragmentaFloristicaetGeobotanica 21, 369-396. 